Мисиева Л.А. Лексико-семантические особенности фразеологических единиц, характеризующих лиц мужского пола в аварском языке

УДК 801.52

DOI: $10.21779 / 2542-0313-2016-31-2-55-60$

\title{
Л.А. Мисиева
}

\section{Лексико-семантические особенности фразеологических единиц, характеризующих лица мужского пола в аварском языке}

Дагестанский государственный университет; Россия, 367001, г. Махачкала, ул. М. Гаджиева, 43a; luizaah_83@mail.ru

В статье рассматриваются аварские гендерные фразеологические единицы, характеризующие мужской характер, поступки и поведение лиц мужского пола, их внешние и внутренние качества. Количественный состав тех или иных семантических групп фразеологических единиц зависит от того, насколько носителями данного языка то или иное качество мужчин актуализируется. Нами использована комплексная методика исследования: сопоставительный и описательный методы. Анализ привел к пониманию того, что слова определенных семантических групп способствуют формированию фразеологических образов и выражению коннотативных значений. Проведенный анализ показывает, что можно выделить те качества, признаки и свойства, которые в сознании носителей языка являются наиболее существенными и формирующими мужской характер, поступки и поведение лиц мужского пола, их внешние и внутренние качества. Естественно, при этом выбираются фразеологические единицы, соответствующие по фразеологическому образу характеризуемым качествам. Это свидетельствует о том, что формирование фразеологических образов, связанных с лицами определенного пола, происходит с конкретной опорой на лексико-грамматический состав исследуемых фразеологических единиц.

Ключевые слова: фразеологические единииы, гендер, аварский язык, лингвокультурология.

Фразеологические единицы среди разных речевых обозначений являются достаточно интересными в лингвистическом плане и культуроносными в лингвокультурологическом аспекте структурами языка.

Говоря об изучении языка и культуры, следует подчеркнуть неразрывность исследования данной проблемы. Исследование особенностей культуры, «отраженных в языке, позволяет ближе подойти к пониманию мировосприятия народа-носителя языка, его образной системы, набора стереотипов. При этом определенный интерес представляет то, как в языке отражаются мир и человек» [11, с. 312].

Фразеологизмы, ориентированные на человека, в том числе по признаку биологического пола и его социально-культурной отнесенности, являются интересным материалом для таких наук, как лингвистика, социолингвистика, этнолингвистика и лингвокультурология.

В ряде опубликованных в последнее время научных статей рассматриваются как лингвистические, так и лингвокультурологические особенности отдельных семантических групп аварских фразеологических единиц: структурно-грамматические особенности [3, с. 260-262], лексический состав аварских паремий [4, с. 32-34] и их морфологосинтаксические и собственно синтаксические особенности как средства формирования паремиологических образов [7, с. 13-17] и др.

Анализ материала показывает, что в аварском языке можно выделить те качества, признаки и свойства, которые в сознании носителей языка являются наиболее сущест- 
Мисиева Л.А. Лексико-семантические особенности фразеологических единиц, характеризующих лиц мужского пола в аварском языке

венными и формирующими мужской характер, поступки и поведение лиц мужского пола, их внешние и внутренние качества.

Естественно, при этом выбираются фразеологические единицы, соответствующие характеризуемым качествам. Продуктивность (количественный состав) тех или иных семантических групп фразеологических единиц зависит от того, насколько носителями данного языка то или иное качество мужчин актуализируется.

1. В аварском языке достаточно существенными для лиц мужского пола оказываются признаки смелости, храбрости, решительности, которые формируют образ стойкого, отважного человека, достаточно ярко противопоставляемого как по фразеологическому образу, так и на коннотативном уровне трусливому мужчине (трусость выступает в качестве достаточно осуждаемого негативного признака):

a) обозначение смелости: бацІ гІадав «бесстрашный, ловкий» (букв. подобный волку), къвекІаб иІудул тинчI «смелый, решительный, мужественный» (букв. орла птенец), рекІель чаран льурав «смелый, отважный» (букв. в сердце сталь положивший, стальное сердце), бахъараб хвалчен гІадав «смелый, отважный» (букв. как вынутый кинжал), кьуру гІадав къвакІарав «крепкий (мужественный) как скала» (букв. крепкий как скала), чаран гІадин къвакІарав «крепкий, мужественный, как сталь», хонжрода квер лъун «не боясь, смело, решительно» (букв. на кинжал руку положив), бацІил ракI «смелый» (букв. волка сердце), чармил ракI «смелый, стойкий» (букв. стали сердце), цІудулаб ракI «смелый» (букв. орла сердце);

б) обозначение трусости: гІанкІил ракI <бугев> «трусливый» (букв. зайца сердце <имеющий>), эбелалъул Мухуума «трус, слабовольный, маменькин сынок» (букв. маменькин Мухума [имя собств.]), ракI хІинкъарав «с трусливым сердцем», ракI гъечІев «трусливый» (букв. сердца не имеющий), хІинкъараб гІанкI «трусливый заяц» и др.

В качестве лексических компонентов, формирующих образ смелого, крепкого мужчины, выступают слова, имеющие для носителей аварского языка, как и для других дагестанских языков, символический характер:

а) названия животных: бай «волк», ичІум «орел». Достаточно часто в аварских фразеологических единицах, отражающих образ человека, в символической функции используются названия животных. Такое явление свойственно разным дагестанским языкам. Так, отмечая факт использования в табасаранских паремиях зооморфного кода культуры, М.А. Гасанова пишет следующее: «Зоонимы часто выступают в качестве универсальной языковой метафоры, своеобразного культурного кода, в которых сущностные признаки человека и взаимоотношения людей раскрываются через наделение определенными качествами представителей животного мира [5, с. 54];

б) названия твердых (прочных) металлов: махx «железо» (ср. махх гІадин къвакІарав «твёрдый, как железо»), чаран «сталь»;

в) названия реалий, существенных в ландшафтном и национально-культурном отношении для носителей языка и данной культуры: кьуру «скала», гамачI «камень», ханжар «кинжал».

2. Признак надежности нередко пересекается с качеством смелости и решительности человека, вместе с тем в исследуемом языке имеют место фразеологические единицы, обозначающие специально и качество надежности: ср. в аварском языке: [ккараб] къо борхулев «человек, на которого можно положиться» (букв. «трудности/испытания поднимающий человек»), гІемер гІакъуба чІамурав «много трудностей поживавший» (в значении «опытный, видавший виды»), божизе бегьулев «надежный человек, который не подведет» (букв. [которому] можно верить), ракI чІарав «надежный; человек, в котором можно быть уверенным» (букв. сердце [в котором] стоит - в смысле «чье-либо 
Мисиева Л.А. Лексико-семантические особенности фразеологических единиц, характеризующих лиц мужского пола в аварском языке

сердце верит в надежность кого-либо»), ракI бащзадав «закадычный, преданный друг» (букв. сердцем равный): ср. РакI бащадав гьудулгун дандчІвазе гьев Минскиялдаса Хунзахъе вачІана «Чтобы встретиться с преданным другом, он из Минска приехал в Хунзах» (Расул Гамзатов), ракI изояв (гъалмагъ) «верный, преданный друг» (букв. одного сердца друг) и некоторые другие.

3. Непременно обозначается такое качество мужчины, как интеллектуальные способности.

Для обозначения данного качества (умный - неумный) используются фразеологические единицы с компонентами-словами различной семантики. Такие структуры, как «имеющий ум» - «не имеющий ума», используются для характеристики и мужчин и женщин: ср. гІакълу буге-в «умный» (букв. имеющий ум), гІакълу буге-й (букв. имеющая ум) «умная» (принадлежность обозначаемого качества лицу мужского или женского пола определяется выделенными выше классными показателями соответствующего мужского или женского класса): ср. гІакълу гьечІе-в «неумный, глупый», гІакълу гьечІе$\check{u}$ «неумная, глупая».

Вместе с тем обозначение интеллектуальных качеств в аварском языке в большей степени актуализируется для лиц мужского пола нежели для лиц женского пола: гъваридав чи «умный, глубокий человек» (букв. глубокий человек), бегІерав чи «умный, способный человек» (букв. острый человек), ракI иІодорав «умный, смекалистый» (букв. с умным сердцем).

Такое явление, характерно не только для аварского языка.

Так, В.А. Маслова отмечает: «Немецкий исследователь Трёмль-Плётц в 1877 г. опубликовала книгу «Язык женщин», в которой утверждает, что дискриминация женщин по языку выражается не только в речевом поведении, где мужчина - всегда ведущий партнер диалога, но и в употреблении слов мужского рода для обозначения женщин (автор, пассажир, врач), употреблении местоимений мужского рода в обобщенном значении (всякий, каждый) и т. д.» [9, с. 125].

Исследователи фразеологии дагестанских языков обращали внимание на тот факт, что в аварском и в других дагестанских языках при обозначении интеллектуальных свойств часто используется слово «сердце», которое обычно в других языках чаще используется для обозначения эмоциональных состояний.

На данное свойство дагестанских языков обращал внимание и С.М. Хайдаков, который утверждал, что, подобно древним народам античности, прадагестанцы и пранахцы центром духовной деятельности считали не мозг, а сердце [10].

В качестве других примеров обозначения интеллектуальных свойств человека можно считать следующие фразеологические единицы аварского языка: гІакълудул ралъад «умный, мудрый» (букв. море ума), бетІер бугев чи «умный, сообразительный человек» (букв. голову имеющий человек), гІелмудул ралъад «умный, образованный человек» (букв. море науки), лъикI гьалулеб хьаг «умный, хорошо соображающий человек (букв. хорошо кипящая кастрюля), бетІер хІалтІулев «умный» (букв. голова у которого работает), данный фразеологизм характеризует также лицо женского пола.

4. Ряд фразеологических единиц в аварском языке обозначает внешние признаки лиц мужского пола.

Некоторые из характеризуемых фразеологизмов связаны с характеристикой лиц мужского пола определенного возраста: иІа гІадал берал (букв. подобные огню глаза), хІехь гІадин вищатав «толстый, полный» (букв. толстый, как чурбан), бугъа гІадин кьарияв «жирный, как бугай»; ср. обозначение внешности женщин: гІучI гІадин тІеренай 
Мисиева Л.А. Лексико-семантические особенности фразеологических единиц, характеризующих лиц мужского пола в аварском языке

«худая, как щепка», бадиса бакъ баккарай «прекрасная, очень красивая» (букв. из глаз которой солнце восходит), тIегь гІадай «очень красивая» (букв. цветку подобная) и др.

Как видно из примеров, внешние качества обозначаются путем сравнения с объектами растительного или животного мира, а также с конкретными предметами, являющимися носителями тех или иных признаков, ассоциативно приписываемых и лицам мужского или женского пола.

5. Фразеологические единицы, декларирующие знатность, социальное положение мужчин: пачалихъазул бутІрул «предводители, чиновники» (букв. голова государства), бодул бетІер // къокъадул бетІер «главнокомандующий, командующий» (букв. глава войска).

Непродуктивность фразеологических единиц такой семантики в аварском языке, скорее всего, объясняется отсутствием реального основания для их возникновения в объективной действительности: мужчины в силу социальных условий не могли занимать социально (общественно) значимое положение, должности, не могли быть богатыми в силу образа жизни и т. д.

6. Фразеологические единицы, обозначающие родственные отношения. Анализ показал, что родное или близкое ассоциируется с матерью, однако глава семьи - это мужчина. Вместе с тем родственные отношения определяются не только отцом и матерью: бестІал вач «сводный брат», бестІал эбел «мачеха», вач гІадинав «очень преданный, надежный» (букв. как брат), гІагараб ракI «родной, преданный человек» (букв. родное сердце).

7. Фразеологические единицы, номинирующие социальную деятельность мужчин. Гендерный анализ данных фразеологических единиц показал, что именно мужчины, а не женщины, были работниками многих сфер деятельности: кверда пиша, махщел бугев «умелец, ремесленник, специалист» (букв. на руке специальность имеющий), ракІазул инженер «специалист высокого класса» (букв. инженер сердец); работников идеологического фронта, учителей, писателей называли инженерами человеческих душ.

8. Фразеологические единицы, обозначающие преступные наклонности мужчин: кІал бегІерал гІункІкІал «воры» (букв. с острым ртом мыши), квер иІадаб бегьарав «начавший войну, интриган» (букв. руку засунувший в огонь), квер мекъав чи «вор» (букв. с неправильной рукой), бер рештІун жо толарев «ловкий вор» (букв. глаз остановившись, ничего не оставляющий).

Проведенный анализ свидетельствует о том, что формирование фразеологических образов, связанных с лицами определенного пола, происходит с конкретной опорой на лексико-грамматический состав исследуемых фразеологических единиц, на лексические значения (как прямые, так и переносные) компонентов, образующих гендерные фразеологические единицы.

Механизмы переосмысления значений, составляющих гендерные фразеологические единицы компонентов, также могут иметь единую основу, с одной стороны, с другой же стороны, имеют место национально обусловленные механизмы и стратегии, мотивированные различными причинами как лингвистического, так и экстралингвистического характера.

Анализ гендерной фразеологии аварского языка с точки зрения национальнокультурной специфики показал ряд особенностей, на которые нами обращается внимание в целях системно-комплексной характеристики исследуемых фразеологизмов.

Проведенный анализ показывает, можно выделить те качества, признаки и свойства, которые в сознании носителей языка являются наиболее существенными и формирующими мужской характер, поступки и поведение лиц мужского пола, их внешние 
Мисиева Л.А. Лексико-семантические особенности фразеологических единиц, характеризующих лиц мужского пола в аварском языке

и внутренние качества. Естественно, при этом выбираются фразеологические единицы, соответствующие по фразеологическому образу характеризуемым качествам.

Продуктивность (количественный состав) тех или иных семантических групп фразеологических единиц зависит от того, насколько носителями данного языка то или иное качество мужчин актуализируется.

В аварском языке достаточно существенными для лиц мужского пола оказываются признаки смелости, храбрости, решительности, которые формируют образ стойкого, отважного человека, достаточно ярко противопоставляемого как по фразеологическому образу, так и на коннотативном уровне трусливому мужчине (трусость выступает в качестве достаточно осуждаемого негативного признака).

\section{Литература}

1. Абакарова М.А. Образ идеального мужчины в английских и лакских пословицах // Фундаментальные исследования. - № 9. - М.: Издательский дом «Академия естествознания», 2014.

2. Абдуразакова 3.Г. Лингвокультурологическая характеристика аварских компаративных паремиологических единиц // Вестник Дагестанского государственного университета. - 2014. - Вып. 3.

3. Абдуразакова 3.Г. Об особенностях структурно-грамматической организации аварских компаративных паремиологических единиц // Историческая и социальнообразовательная мысль. - № 1 (23) - Краснодар, 2014.

4. Алиханова Л.Г. К вопросу о лексическом (компонентном) составе фразеологических единиц со значением пространства в аварском языке // Андийские языки среди языков народов Дагестана. Материалы научно-практической конференции-презентации. 6-8 июня 2011 г. - Махачкала, 2011.

5. Гасанова М.А. Табасаранские пословицы и поговорки: лингвистический и лингвокультурологический аспекты: автореф. дис. ... д. филол. наук. - Махачкала, 2015.

6. Гасанова М.A. История паремиологических исследований дагестанских языков // Современные проблемы науки и образования. - Вып. 6. - Пенза: Издательский дом «Академия естествознания», 2014.

7. Магомедова А.Н. Морфолого-синтаксический состав аварских паремиологических единиц как средство формирования паремиологических образов // Вестник Дагестанского государственного университета. - 2012. - Вып. 3.

8. Магомедханов М.М. Аварско-русский фразеологический словарь. - Махачкала, 1993.

9. Маслова В.А. Лингвокультурология. - М., 2004.

10. Хайдаков С.M. Сравнительно-сопоставительный словарь дагестанских языков. - М., 1973.

11. Харченкова Л.И., Шашков Ю.А. Образ человека в зеркале русского и испанского языков // Логический анализ языка. Образ человека в языке и культуре. - М., 1999.

Поступила в редакичию 25 марта 2016 г. 
Мисиева Л.А. Лексико-семантические особенности фразеологических единиц, характеризующих лиц мужского пола в аварском языке

UDC 801.52

DOI: $10.21779 / 2542-0313-2016-31-2-55-60$

\section{Lexico-semantic features of phraseological units characterizing male gender in the Avar language}

\section{L.A. Misieva}

Dagestan State University; Russia, 367001, Makhachkala, M. Gadzhiev st., 43a; luizaah_83@mail.ru

The article studies gender phraseological units describing male character in the Avar language, his actions and behavior, inner and outer traits. The productivity of the phraseological semantic groups depends on the fact how the speakers actualize the characteristic feature of a man. During the research we used the complex method: comparative and descriptive. The analysis has shown that the words of some semantic groups contribute to the formation of the phraseological images and the expression of connotative meanings. The research has shown that we can outline the traits, factors and qualities which are the most significant and form male character, behavior and actions, his inner and outer traits. The phraseological units used for this purpose are relevant to the qualities implied. The research testifies that the formation of phraseological images of male gender is based on the lexical and grammatical structure of the phraseological units under research.

Keywords: phraseological units, gender, the Avar language, cultural linguistics.

Received 25 March, 2016 